\title{
Realism Is the Order of the Day for Bioremediation
}

\author{
BERNARD DIXON
}

W ith $\$ 650$ million in claims by the Dutch government currently pending against industrial polluters of the soil, Amsterdam was an apposite choice for November's international workshop on bioremediation. Sponsored by the Organization for Economic Cooperation and Development (OECD, Paris) and the Netherlands Ministry of Economic Affairs (the Hague), it explored the efficacy of, and constraints on, using microorganisms for environmental cleansing.

Recent progress in waste gas treatment has been particularly impressive. Cees Buisman of Paques BV, based in Balk, the Netherlands, described the successful operation of a small commercial plant that converts sulfur dioxide to elemental sulfur and which, later this year, will be followed by a demonstration plant for a 300-megawatt, coal-fired power plant. Other Dutch companies are using a variety of ingenious biofilters, biotricking filters, and bioscrubbers to remove inorganic gases and hydrocarbons from air and off-gases.

Karl Engesser from the University of Stuttgart in Germany described pilot plants with very high elimination rates, using fungi, for example, to remove up to $150 \mathrm{~g}$ per cubic meter of styrene from plastics industry off-gas. "Techniques of this sort are of outstanding quality because they do not shift compounds of environmental concern from air to other compartments, but degrade them to $\mathrm{CO}_{2}$ and water," he said. "Yet intrinsic $\mathrm{CO}_{2}$ production is minimal, as no extra fuel is needed, while no extra $\mathrm{CO}_{2}$ is produced as it is during the incineration of activated charcoal."

Engesser insists that biological methods are usually the most cost-effective way of cleaning waste gases. They appear to have a rosy future, with investment rising rapidly in response to the increasing demands of clean air legislation in Europe.

With regard to the conjectural hazard of biofilters emitting pathogenic organisms, at least two speakers categorized this risk as "negligible." It would, of course, be churlish to observe that microorganisms are relentless opportunists. Only relatively recently did we learn that such a commonplace bacterium as Legionella pneumophila can cause lethal pneumonia when released in an aerosol by improperly maintained cooling towers and air conditioning systems.

The status of soil bioremediation is harder to de- fine. Here too significant advances were reported, including a process developed by British Nuclear Fuels (Preston, U.K.) that uses indigenous microorganisms to generate sulfuric acid and mobilize toxic heavy metals in contaminated land, and a Japan Environment Agency (Tokyo) trial in which methane and oxygen are injected to stimulate the degradation by methanotrophs of trichlorothylene in soil at a former electronics factory.

Despite such specific successes, much of the talk in Amsterdam was of the need for validation, models, and theory that could consolidate soil bioremediation as a discipline. The problem is not simply that of bridging the gap between laboratory and field, but of the equal difficulty of improving the predictability of performance. While ex situ operations are relatively more reliable, in situ work can give markedly different results in apparently similar sites. These reflect differences in, for example, the physical nature of the sites, in microbial communities, and in the bioavailability of pollutants.

Until today's case-by-case approach is superseded by a more rigorous, predictive discipline, the soil bioremediators will need to work hard to convince skeptics that living organisms, for all their inherent variability, can be harnessed in a satisfactory way. Bioremediators may even find data on the costeffectiveness of their technique rejected in favor of more expensive chemical methods simply because these are familiar and seem more reliable.

Many workshop speakers deliberately urged a greater sense of realism, and acceptance that total purity is unattainable. One such voice was that of Richard Bewley of Dames \& Moore in Manchester, U.K., who played a major role in the bioremediation of the site of the former Greenbank Gas Works (Preston) in the U.K. some years ago. Bewley pointed out that even land that retains some contamination after biotechnological cleansing may be more attractive to a purchaser than an ostensibly cleaner but uncharacterized site simply because it is so thoroughly understood.

Together with warnings of the need to monitor more carefully the ecotoxicity of bioremediation products (including intermediates) and to pay greater attention to the long-term stability of treated sites, these comments betoken much greater realism than was shown by dizzy optimists a decade ago. //I 